\title{
HUBUNGAN POLA KONSUMSI KOPI TERHADAP KEJADIAN GASTRISTIS PADA MAHASISWA MUHAMMADIYAH PAREPARE
}

\section{Relationship of Coffee Consumtion Pattern To The Event of Gastristis In Students of Muhammadiyah Parepare.}

\author{
Muhammad Ishak Ilham, Haniarti, Usman \\ (Program Studi Kesehatan Masyarakat Fakultas Ilmu Kesehatan Universitas Muhammadiyah \\ Parepare) \\ ( bemfkmumpar@gmail.com, 082292682014 )
}

\begin{abstract}
ABSTRAK
Kafein di dalam kopi dapat mempercepat proses terbentuknya asam lambung. Hal ini membuat produksi gas dalam lambung berlebih sehingga sering mengeluhkan sensasi kembung di perut. Responden yang sering meminum kopi beresiko 3,57 kali menderita gastritis dibandingkan dengan yang tidak sering meminum kopi.Tujuan penelitian ini adalah untuk mengidentifikasi hubungan pola konsumsi kopi terhadap kejadian gastritis pada Mahasiswa Univesitas Muhammadiyah Parepare.Jenis penelitian ini menggunakan metode deskriptif analitik dengan pendekatan cross sectional. Populasi yaitu mahasiswa yang aktif secara keseluruhan mahasiswa di Universitas Muhammadiyah Parepare sebanyak 8.891 orang. Sampelnya sebanyak 99 orang yang dihitung dengan menggunakan rumus slovin. Teknik pengambilan sampel dilakukan Purposive Sampling Pengumpulan data dengan menggunakan kuesioner. Hasil penelitian ini menunjukkan bahwa ada hubungan pola konsumsi kopi terhadap kejadian gastritis pada Mahasiswa Universitas Muhammadiyah Parepare. Untuk penderita gastristris maupun bukan penderita gastristis sebaiknya membatasi konsumsi kopi.
\end{abstract}

\section{Kata kunci: Pola konsumsi, kopi, gastristis}

\section{ABSTRACT}

The caffeine in coffee can accelerate the process of stomach acid formation. This makes the production of excess gas in the stomach so often complain of bloating sensation in the stomach. Respondents who frequently drank coffee were at risk 3.57 times suffering from gastritis compared to those who did not drink coffee often. The purpose of this study was to identify the relationship of coffee consumption patterns to the incidence of gastritis in Parepare Muhammadiyah University Students. This type of research uses descriptive analytic methods with cross sectional approach. The population is all students who are active students at the University of Muhammadiyah Parepare as many as 8,891 people. The sample of 99 people was calculated using the Slovin formula. The sampling technique used was Purposive Sampling Data collection using a questionnaire. The results of this study indicate that there is a relationship between coffee consumption patterns and the incidence of gastritis in Muhammadiyah Parepare University students. For patients with gastritis and non-gastritis sufferers should limit coffee consumption.

Keywords: Consumption patterns, coffee, gastristis 


\section{PENDAHULUAN}

Kopi menjadi salah satu minuman paling popular dan digemari di seluruh dunia, salah satunya di Indonesia. Satu cangkir kopi menjadi perangkat simbol yang luar biasa karena tidak hanya berfungsi sebagai penghilang rasa kantuk atau teman begadang, tetapi sebagai kode simbolik yang digunakan oleh sebagian kalangan penikmatnya untuk mengaktualisasikan keberadaan mereka dalam kelompok sosial.

Saat ini kopi merupakan komoditas nomor dua yang paling banyak diperdagangkan setelah minyak bumi. Berdasarkan Food and Agriculture Organization (FAO), total 6,7 juta ton kopi diproduksi dalam kurun waktu 1998-2000 dan diperkirakan akan meningkat $1,9 \%$ pada tahun 2010 menjadi 7 juta ton. Konsumsi kopi juga diproyeksikan meningkat sebesar $0,4 \%$ per tahun dari 6,7 juta ton pada tahun 1998-2000 menjadi 6,9 juta ton pada tahun $2010 .^{1}$ Indonesia merupakan salah satu produsen kopi terbesar di dunia, tetapi memiliki nilai konsumsi kopi per kapita yang masih relatif rendah yaitu sekitar 70.000 ton/tahun atau 0,5 kg/orang/tahun, jika dibandingkan dengan negara-negara lain seperti
Finlandia, Norwegia, Denmark, Austria, Jerman, dan Belgia yang telah mencapai sekitar 8-11 kg/orang/tahun. ${ }^{2}$

Indonesia berada di tingkat konsumsi 4-5 juta karung per tahun, atau sekitar 300.000 ton dengan jumlah penduduk 255 juta jiwa. Angka ini kontras dengan Jepang yang, meski tidak memproduksi kopi, tercatat menjadi 'negara tradisional pengkonsumsi kopi dengan tingkat konsumsi sebesar 7,5 juta karung per tahun, dengan jumlah penduduk 126 juta jiwa. International Coffee Organization mencatat bahwa petumbuhan peminum kopi di Indonesia lebih dari $8 \%$, angka ini lebih tinggi dari pertumbuhan peminum kopi secara global yang hanya 6\%. Hal ini mendorong kemunculan coffee shop di berbagai kawasan seperti perkantoran, kampus, hingga residensial.

Di sisi lain kopi sering dikaitkan dengan sejumlah faktor risiko penyakit jantung koroner, termasuk meningkatkan tekanan darah dan kadar kolesterol darah. Meskipun dikatakan sebagai penyebab berbagai penyakit khususnya hipertensi, namun berbagai hasil studi epidemiologi mengenai efek konsumsi kopi terhadap tekanan darah tidak konsisten, beberapa menunjukkan hubungan yang positif, ada yang 
mengatakan tidak ada hubungannya, bahkan beberapa menunjukkan ada hubungan terbalik. Hal ini dapat diduga karena kandungan polifenol terutama chlorogenic acid (CGA) pada kopi yang digunakan sebagai antioksidan yang dapat menurunkan toksik radikal bebas dalam tubuh.

Kafein di dalam kopi dapat mempercepat proses terbentuknya asam lambung. Hal ini membuat produksi gas dalam lambung berlebih sehingga sering mengeluhkan sensasi kembung di perut. Responden yang sering meminum kopi beresiko 3,57 kali menderita gastritis dibandingkan dengan yang tidak sering meminum kopi.Gastritis merupakan salah satu penyakit yang umumnya diderita oleh kalangan remaja, yang disebabkan oleh berbagai faktor misalnya tidak teraturnya pola makan, gaya hidup dan salah satunya yaitu meningkatnya aktivitas (tugas perkuliahan) sehingga mahasiswa tidak sempat untuk mengatur pola makannya dan malas untuk makan.

Insiden Gastritis di dunia sekitar 1,8 - 2,1 juta dari jumlah penduduk setiap tahun. Menurut data dari World Health Organization (WHO) tahun 2004, persentase dari angka kejadian gastritis di dunia, diantaranya Inggris 22,0\%, China 31,0\%, Jepang 14,5\%, Kanada 35,0\%, dan Perancis 29,5\%.
Inside terjadinya gastritis di Asia Tenggara sekitar 583.635 dari jumlah penduduk setiap tahunnya. Prevalensi gastritis yang dikonfirmasi melalui endoskopi pada populasi di Shanghai sekitar 17,2\% yang secara substantial lebih tinggi daripada populasi di barat yang berkisar $4,1 \%$ dan bersifat asimptomatik.

Data untuk Indonesia menurut WHO angka kejadian gastritis pada beberapa daerah di Indonesia cukup tinggi dengan prevalensi 274,396 kasus dari 238.452.952 jiwa penduduk atau sebesar 40,8\%. Berdasarkan profil kesehatan di Indonesia tahun 2012, gastritis merupakan salah satu penyakit dalam 10 penyakit terbanyak pada pasien rawat inap di rumah sakit di Indonesia dengan jumlah kasus 30.154 kasus $(4,9 \%)$. Berdasarkan hal tersebut maka penelitian mengenai hubungan pola konsumsi kopi terhadap kejadian gastritis pada mahasiswa Universitas Muhammadiyah Parepare penting untuk dilakukan. Persentase dari angka kejadian gastritis di Indonesia adalah 40,8\%. Angka kejadian gastritis pada beberapa daerah di Indonesia cukup tinggi dengan prevalensi 274,396 kasus dari 238,452,952 jiwa penduduk. Gastritis adalah masalah kesehatan yang sering terjadi pada masyarakat Indonesia. 
Gastritis yang terjadi di Negara maju sebagian besar dialamiusia tua. Hal ini berbeda dengan negara berkembang yang banyak dialami usia muda. Kasus gastritis umumnya terjadi pada penduduk yang berusia lebih dari 60 tahun, 57,8\% penderita dan gastritis berusia $\geq 40$ tahun, $77,8 \%$. Penyebab gastritis dibedakan atas faktor internal yaitu adanya kondisi yang memicu pengeluaran asam lambung yang berlebihan dan faktor eksternal yang menyebabkan iritasi dan infeksi. Beberapa penyebab gastritis adalah menggunakan obat aspirin atau antiradang non steroid, infeksi kuman Helicobacter pylori, kebiasaan minumminuman beralkohol, memiliki kebiasaan merokok, sering mengalami stress dan kebiasaan minum kopi.

Bila penyakit gastritis ini terus dibiarkan, akan berakibat semakin parah dan akhirnya asam lambung akan membuat luka-luka (ulkus) yang dikenal dengan tukak lambung. Bahkan bisa juga disertai muntah darah. ${ }^{3}$ gastritis yang tidak ditangani dengan tepat akan menimbulkan komplikasi yang mengarah kepada keparahan yaitu kanker lambung.

Badan penelitian kesehatan dunia WHO mengadakan tinjauan terhadap delapan Negara dunia dan mendapatkan beberapa hasil presentase angka kejadian gastritis di dunia. Dimulai dari Negara yang kejadian gastritisnya paling tinggi yaitu Amerika dengan presentase mencapai $47 \%$ kemudian di ikuti oleh India dengan presentase mencapai $43 \%$, lalu dibeberapa negara lainnya seperti Inggris $22 \%$, China $31 \%$, Jepang 14,5\%, Kanada $35 \%$, Perancis $29,5 \%$ dan Indonesia 40,85\%. Angka kejadian gastritis pada beberapa daerah di Indonesia cukup tinggi dengan prevalensi 274,396 kasus dari 238,452,952 jiwa penduduk. Angka kejadian infeksi Gastritis pada beberapa daerah di Indonesia menunjukkan data yang cukup tinggi.

Kejadian pertumbuhan peminat kopi juga ikut berdampak di seluruh daerah di Indonesia baik itu tingkat kabupaten maupun kota, dimana Kota Parepare sebagai kota jasa juga termasuk yang merasakan hadirnya fenomena kopi day ini, hampir diseluruh sudut Kota Parepare terdapat usaha yang menyajikan seduhan aneka macam minuman bernuansa kopi, warung kopi sampai tingkat cafe and resto semuanya menyajikan minuman kopi. Dan khususnya kalangan mahasiswa umpar juga memiliki peminat konsumsi kopi cukup tinggi, kegiatan diskusi aktivis mahasiswa maupun hanya sekedar kerja tugas kelompok, hidangan minuman yang dipesan ataupun disajikan adalah kopi. Dari uraian di atas, peneliti tertarik 
untuk mengetahui "Hubungan pola konsumsi kopi terhadap kejadian Gastritis pada Mahasiswa Universitas Muhammadiyah Parepare".

\section{BAHAN DAN METODE}

Penelitian ini menggunakan metode penelitian deskriptif analitik dengan pendekatan cross sectional, di mana data yang berkaitan dengan variable bebas dan variable terikat dikumpulkan dalam waktu yang bersamaan .Desain cross sectional digunakan berdasarkan tujuan penelitian, yaitu untuk mengetahui hubungan pola konsumsi kopi terdahap kejadian Gastritis pada Mahasiswa Universitas Muhammadiyah Parepare.

Adapun lokasi penelitian dilakukan di kampus Universitas Muhammadiyah Pareparepada bulan Juni-Juli 2018. Instrumen dalam penelitian ini adalah menggunakan kuesioner. Kuesioner penelitian ini terdiri dari 5 pertanyaan tentang pola konsumsi kopi dan 5 pertanyaan untuk kejadian gastritis yang menggunakan skala Guttman dengan jawaban "Ya" atau "Tidak". Untuk jawaban "Ya" diberi nilai 2, bila jawaban "Tidak" diberi nilai 1 .

Populasi dalam penelitian ini adalah mahasiswa yang aktif secara keseluruhan di Mahasiswa Universitas
Muhammadiyah Parepare sebanyak 8.891 orang. Sampel dalam penelitian ini adalah seluruh mahasiswa Universitas Muhammadiyah Parepare dengan jumlah sampel berjumlah 99. Analisis yang digunakan adalah analisis univariat dan analisis bivariat, pada analisis ini digunakan Pearson Chi Square. ${ }^{4}$

\section{HASIL}

Berdasarkan hasil penelitian yang dilakukan pada mahasiswa UM Parepare, maka karakteristik responden yang dimaksud adalah usia, jenis kelamin dan fakultas/jurusan. Merujuk dari hasil penelitian yang didapatkan dilapangan mengenai gambaran umum karakteristik responden yang terdiri dari jenis usia, jenis kelamin, dan fakultas/jurusan maka distribusi responden berdasarkan karakteristik responden mahasiswa UM Parepare dapat dilihat pada Tabel 1 yaitu responden yang terpilih,responden dengan umur tertinggi yaitu pada umur 22 sebanyak 45 responden atau $45,5 \%$ dan terendah pada umur 25 tahun sebanyak 1 responden atau $1,1 \%$. Untuk jenis kelamin lakilaki sebanyak 76 responden atau $76,8 \%$ dan perempuan sebanyak 23 responden atau 23,2\%. Sedangkan untuk fakultas/jurusan tertinggi yaitu pada fakultas/jurusan fikes sebanyak 23 responden atau 23,2\% 
dan terendah sebanyak 6 responden atau $6,1 \%$.

Berdasarkan hasil penelitian maka diperoleh distribusi pola konsumsi kopi mahasiswa Universitas Muhammadiyah Parepare. Berdasarkan pola konsumsi kopi dapat dilihat pada Tabel 2 yaitu menunjukkan bahwa dari 99 responden sebanyak 79 responden $(79,8 \%)$ yang sering mengkonsumsi kopi dan sebanyak 20 responden $(20,2 \%)$ yang jarang mengkonsumsi kopi.

Berdasarkan hasil penelitian yang dilakukan melalui wawancara dengan mengisi kuesioner maka diperoleh distribusi kejadian gastritis mahasiswa Universitas Muhammadiyah Parepare. Berdasarkan kejadian gastritis dapat dilihat pada Tabel 3 yaitu menunjukkan bahwa dari 99 responden sebanyak 96 responden $(97,0 \%)$ yang mengalami kejadian gastritis dan sebanyak 3 responden $(3,0 \%)$ yang tidak mengalami kejadian gastritis.

Berdasarkan hasil penelitian yang dilakukan pada responden mahasiswa UM Parepare untuk melihat hubungan pola konsumsi kopi terhadap kejadian gastritis mahasiswa UM Parepare dapat dilihat pada Tabel 4 diketahui bahwa responden yang sering mengkonsumsi kopi tergolong mengalami kejadian gastritis sebanyak 79 orang $(98,0 \%)$ dan 1 orang $(1,3 \%)$ tidak mengalami kejadian gastritis. Sedangkan yang jarang mengkonsumsi kopi mengalami kejadian gastritis sebanyak 17 orang $(89,5 \%)$ dan 2 orang (10,5\%) tidak mengalami kejadian gastritis. Berdasarkan hasil uji Fisher Exactdapat diketahui bahwa nilai signifikan $p>a$ (0,093>0,05), maka $\mathrm{H}_{\mathrm{a}}$ ditolak dan $\mathrm{H}_{0}$ diterima, sehingga dapat disimpulkan bahwa tidak ada hubungan yang signifikan antara pola konsumsi kopi dengan kejadian gastritis.

\section{PEMBAHASAN}

Perkembangan kopi yang pesat membuat minuman ini sudah menjadi bagian dari kebiasaan dan budaya masyarakat pedesaan maupun perkotaan. Konsumsi kopi berbeda dengan konsumsi minuman lainnya, karena faktor ketenangan dan kefokusan yang diperoleh tanpa efek samping seperti minuman beralkohol. Berdasarkan data pada tabel3 menunjukkan bahwa dari 99 responden sebanyak 79 responden $(79,8 \%)$ yang sering mengkonsumsi kopi dan sebanyak 20 responden $(20,2 \%)$ yang jarang mengkonsumsi kopi.

Adapun tingkat kegemaran konsumsi kopi di Universitas Muhammadiyah Parepare sangat tinggi dimana para mahasiswa sudah menjadikan kopi sebagai minuman trendsetter, bahkan kopi sudah menjadi 
daya tarik tersendiri buat para mahasiswa dikala senggang, baik pada saat mengerjakan tugas maupun diskusi bersama teman teman mahasiswa. dalam perbandingannya jumlah laki laki lebih banyak dibandingkan perempuan, sehingga persentasenya mencapai 76,8 $\%$, ini menjadi satu terobosan kemajuan sumber daya alam lokal kita, mampu diterima seluruh kalangan dan menjadi minuman paling digemari pada zaman Revolusi Industri 4.0 saat ini. ${ }^{5}$ yang menilai 12 fungsi kognitif pada pria dan wanita berdasarkan lama mengkonsumsi kopi yang sama menunjukkan wanita memiliki fungsi kognitif lebih baik terhadap perasa kopi dibanding pria. Keseragaman peubah rasa kopi oleh panelis wanita dapat disebabkan oleh rendahnya konsumsi kopi oleh panelis wanita, yang berdasarkan karakter responden pria lebih sering mengkonsumsi kopi daripada wanita. Hasil uji hedonik yang dihasilkan responden wanita memberikan keragaman yang lebih rendah dibandingkan responden pria. Hal ini disebabkan pria cenderung lebih sering mengkonsumsi kopi dibandingkan wanita.

Konsumsi kopi di dunia meningkat cukup tajam, yaitu rata-rata $1,7 \mathrm{~kg}$ per kapita per tahun. Begitu pula konsumsi kopi di Indonesia, meningkat rata-rata lebih dari 7 persen per tahun. Hal ini disebabkan minum kopi sudah menjadi gaya hidup atau trend. Ada banyak jenis kopi yang beredar di pasaran, tetapi secara umum yang terbesar adalah jenis arabika dan robusta. Kopi arabika dan robusta berbeda dari segi penampilan fisik, kesesuaian agroekologi (iklim dan ketinggian tempat), sifat kimia, dan penyajiannya yang berpengaruh terhadap citarasanya. Intensitas cahaya mempengaruhi citarasa dan kadar kafein kopi robusta. Intensitas cahaya sedang akan menghasilkan citarasa yang optimal, sedangkan intensitas cahaya yang semakin tinggi akan mengakibatkan kadar kafein menjadi semakin tinggi. ${ }^{6}$ Ketinggian tempat juga berpengaruh terhadap optimalisasi fermentasi yang pada akhirnya mempengaruhi citarasa ${ }^{7}$. Semakin tinggi tempat pertanaman maka citarasa kopinya semakin baik. Kopi arabika memiliki citarasa yang khusus, namun body-nya tidak sebaik robusta dan target pasarnyapun khusus, sedangkan kopi robusta memiliki pasar yang lebih strategis karena bisa ditanam di ketinggian rendah, toleran terhadap hama dan penyakit, mengandung antioksidan dan kafein tinggi. Kopi instan yang beredar di pasaran Indonesia merupakan jenis robusta, mempunyai rendemen hasil ekstraksi yang tinggi, 
sementara kopi arabika biasanya digunakan untuk memperbaiki citarasa dan aroma. ${ }^{8}$

Gastritis merupakan salah satu masalah kesehatan yang ada dimasyarakat dan terkhusus pada mahasiswa universitas muhammadiyah parepare. Pada tahun 2014 gastritis termasuk dalam sepuluh penyakit terbanyak Dikota Parepare. Berdasarkan data pada tabel 4 menunjukan bahwa dari 99 responden, sebanyak 96 responden $(97,0 \%)$ yang mengalami kejadian gastritis dan sebanyak 3 responden $(3,0 \%)$ yang tidak mengalami kejadian gastritis.

Adapun perbandingannya tidak cukup signifikan karena jumlah laki laki penderita gastritis lebih banyak dibandingkan perempuan, artinya pengonsumsi kopi diuniversitas muhammadiyah parepare dominan laki laki dan yang terkena penyakit gastritis juga dominan laki laki, sehingga dapat kita berasumsi bahwa konsumsi kopi menjadi salah satu penyebab utama dalam timbulnya penyakit gastritis ini.

Kopi adalah minuman yang terdiri dari berbagai jenis bahan dan senyawa kimia, termasuk lemak, karbohidrat, asam amino, asam nabati yang disebut dengan fenol, vitamin dan mineral. Kopi diketahui merangsang lambung untuk memproduksi asam lambung sehingga menciptakan lingkungan yang lebih asam dan dapat mengiritasi mukosa lambung.

Hasil analisis bivariat menunjukan bahwa tidak ada hubungan yang signifikan antara pola konsumsi kopi dengan kejadian gastritis mahasiswa Universitas Muhammadiyah Parepare dengan menggunakan Uji Fisher Exactdiperoleh nilai $\rho=0,093$, nilai tersebut lebih besar dari $\alpha(0,05)$. Hasil penelitian ini tidak sejalan dengan pendapat wira \& broto 2008, Efek dari kafein bisa merangsang keluarnya asam lambung. Konsumsi kafein yang berlebihan membuat produksi asam lambung naik serta masalahmasalah saluran gastrointestinal disebabkan oleh kelebihan konsumsi kafein, termasuk ulcer (luka) di lambung dan kerongkongan. Ini memperbesar risiko seseorang terkena penyakit lambung, tukak lambung, dan tukak usus halus. Kafein dapat menyebabkan lambung memproduksi asam tambahan sehingga bisa menimbulkan masalah pada saluran pencernaan.

Hasil penelitian ini juga tidak sejalan dengan pendapat Iin Inayah, 2008. Yang menjelaskan bahwa dengan mengkonsumsi kafein berlebih dapat meningkatkan produksi asam lambung, sehingga terjadi iritasi mukosa lambung 
yang berakibat seseorang menderita gastritis. $^{9}$

Berdasarkan pembahasan diatas menyatakan bahwa mengkonsumsi kopi yang berlebihan tidakterlalu berpengaruh terhadap kejadian gastritis karena penyakit gastritis Ini sebabkan oleh beberapa faktor seperti pola makan, merokok dan stres.

Pola makan seperti jenis makanan dan banyaknya makanan yang dikonsumsi termasuk dengan sering mengonsumsi makanan yang berisiko terkena gastritis terlebih lagi apabila lambung dibiarkan kosong slama 3-4 jam lebih akan memicu timbulnya berbagai penyakit dan dapat terkena gastritis. Orang yang memiliki pola makan tidak teratur, mudah terserang penyakit ini. Pada saat perut harus diisi, tapi dibiarkan kosong, atau ditundanya pengisian, asam lambung akan mencerna lapisan mukosa lambung, karena ketika kondisi lambung kosong, akan terjadi gerakan peristaltik lambung bertambah intensif yang akan merangsang peningkatan produksi asam lambung sehingga dapat timbul rasa nyeri diulu hati.

Gaya hidup yang tidak baik seperti kebiasaan mengkonsumsi rokok juga cukup berpengaruh terhadap penyakit gastritis ini karena Rokok adalah silinder kertas yang berisi daun tembakau cacah. Dalam sebatang rokok, terkandung berbagai zat-zat kimia berbahaya yang berperan seperti racun. Dalam asap rokok yang disulut, terdapat kandungan zat-zat kimia berbahaya seperti gas karbon monoksida, nitrogen oksida, amonia, benzene, methanol, perylene, hidrogen sianida, akrolein, asetilen, bensaldehid, arsen, benzopyrene, urethane, coumarine, ortocresol, nitrosamin, nikotin, tar, dan lain-lain.Efek rokok pada saluran gastrointdstinal antara lain melemahkan katup esofagus dan pilorus, meningkatkan refluks, mengubah kondisi alami dalam lambung, menghambat sekresi bikarbonat pankreas, mempercepat pengosongan cairan lambung, dan menurunkan $\mathrm{pH}$ duodenum. Sekresi asam lambung meningkat sebagai respon atas sekresi gastrin atau asetilkolin. Selain itu, rokok juga mempengaruhi kemampuan cimetidine (obat penghambat asam lambung) dan obat-obatan lainnya dalam menurunkan asam lambung pada malam hari, dimana hal tersebut memegang peranan penting dalam proses timbulnya peradangan pada mukosa lambung.Rokok dapat mengganggu faktor defensif lambung (menurunkan sekresi bikarbonat dan aliran darah di mukosa), memperburuk peradangan, dan berkaitan erat dengan komplikasi 
tambahan karena infeksi $H$. pylori. Merokok juga dapat menghambat penyembuhan spontan dan meningkatkan risiko kekambuhan tukak peptik.

Akibat negatif dari rokok, sesungguhnya sudah mulai terasa pada waktu

orang baru mulai menghisap rokok.Dala $\mathrm{m}$ asap rokok yang membara karena diisap, terdapat kurang lebih 3000 macam bahan kimia diantaranya acrolein, tar, nikotin, asap rokok, gas $\mathrm{CO}$.

Nikotin itulah yang menghalangi terjadinya rasa lapar. Itulah sebabnya seseorang menjadi tidak lapar karena merokok, sehingga akan meningkatkan asam lambung dan dapat menyebabkan gastritis.

Stres juga menjadi salah satu faktor penyebab terhadap kejadian gastritis karena Stres adalah suatu respon non spesifik tubuh terhadap setiap kebutuhan dan stimuli konsep yang lebih bernuansa biologis karena perubahan temoeratur mekanik. Dan stres adalah respon tubuh tidak spesifik terhadap kebutuhan tubuh yang terganggu. Stres merupakan suatu fenomena universal yang terjadi dalam kehidupan sehari-hari dan tidak dapat dihindari dan akan dialami oleh setiap orang. Stres memberikan dampak secara total pada individu seperti dampak: fisiksosial, intelektual, psikologis, dan spiritual. Itulah sebabnya mengapa stres dapat mempengaruhi proses terjadinya penyakit gastritis.

\section{KESIMPULAN DAN SARAN}

Berdasarkan hasil penelitian yang telah dilakukan pada mahasiswa Universitas Muhammadiyah Parepare, maka dapat disimpulkan bahwa tidak ada hubungan pola konsumsi kopi terhadap kejadian gastritis mahasiswa Universitas Muhammadiyah Parepare denganm enggunakan hasil uji Fisher Exactd apat diketahui bahwa nilai signifikan $p>a$ $(0,093>0,05)$. Adapun saran yang dapat diajukan untuk mencapai tujuan dari penelitian ini adalah diharapkan kepada mahasiswa Univeritas Muhammadiyah Parepare untuk yang penderita gastritis maupun bukan penderita gastritis sebaiknya membatasi konsumsi kopi serta kepada peneliti selanjutnya diharapkan dapat melakukan penelitian dengan memperluas cakupan dan wilayah penelitian serta mengkaji dengan baik variable yang belum diteliti dalam penelitian ini, dengan maksud untuk memperkaya kajian pada bidang Ilmu Kesehatan Masyarakat terkhusus pada bidang Gizi.

\section{DAFTAR PUSTAKA}


1. Anggita N. Hubungan Faktor Konsusmsi dan Karakteristik Individu dengan Persepsi Gangguan Lambung pada Mahasiswa Penderita Gangguan Lambung di Pusat Kesehatan Mahasiswa Universitas Indonesia Tahun 2011. 2012. [Skripsi]. Jakarta. FKM Universitas Indonesia [Diakses 01 April 2018 waktu 15:00].

2. Angkow J, Robot F, Onibala F. Faktor-Faktor yang Berhubungan dengan Kejadian Gastritis di Wilayah Kerja Puskesmas Bahu Kota Manado. 2014. Manado. Universitas Sam Ratulangi. [Diakses 20 maret 2018 waktu 11:00].

3. Aprianto. Faktor Risiko Gastritis pada Pasien di Rumah Sakit Umum

Daerah Lubuan Baji dan Rumah Sakit Pelamonia Tinkat II Kota Makassar Tahun 2009. Makassar; 2009. [Diakses 22 Maret 2018 waktu 19:00].

4. Caldwell. Berhenti Merokok. Yogyakarta Pustaka Populer; 2009.

5. Gustin RK. Faktor-Faktor yang Berhubungan dengan Kejadian Gastritis pada Pasien yang Berobat Jalan di Puskesmas Gulai Buncah Kota Bukit Tinggi Tahun 2011. 2011. [tesis]. Padang. UNAND. [Diakses 30 Maret 2018 waktu 22:00].
6. Hardinsyah. 2009. Polifenol dan Kopi Serta Manfaatnya Bagi Kesehatan. Sambutan Ketua Umum Pergizi Pangan Indonesia Pada Pembukaan Diskusi Ilmiah Polifenol Dan Kopi Serta Manfaatnya Bagi Kesehatan. Jakarta: Four Seasons Hotel, 4 April 2009. [Diakses 09 Juli 2018 waktu 21:00].

7. Kemenkes. 2015. Rencana Strategis Kementrian Kesehatan Tahun 20152019. Keputusan Menteri Kesehatan Republik Indonesia Nomor HK.02.02/MENKES/52/2015.

8. Mattioli AV. Coffee and Caffeine Effects on Hypertension. Current Hypertension Reviews; 2007: 3(4): 250-254. [Diakses 27 maret 2018 waktu 20:00].

9. Iin Inayah. Pengaruh Pemberian Kopi Dosis Bertingkat Per Oral 30 Hari Terhadap Gambaran Histopatologi Hepar Tikus Wistar. Universitas Diponegoro. Semarang; 2008. [Diakses 27 Maret 2018 Waktu 20.00].

10. Widyotomo S, Sri M. Kafein: Senyawa Penting Pada Biji Kopi. Warta Pusat Penelitian Kopi dan Kakao Indonesia; 2007: 23(1): 44 50.

11. Zilmawati R. Faktor-Faktor yang Berhubungan dengan Gejala Gastritis pada Mahasiswa Tingkat 
IV Fakultas Kesehatan Masyarakat

[Skripsi]. Padang; 2009. [Diakses 05

Universitas Baiturrahmah Padang

Maret 2018 waktu 19:00] 


\section{LAMPIRAN}

Tabel 1. Distribusi karakteristik mahasiswa Universitas Muhammadiyah Parepare.

\begin{tabular}{lcc}
\hline Karakteristik responden & Frekuensi (f) & Persen (\%) \\
\hline Umur (tahun) & & \\
19 & 4 & 4,0 \\
20 & 6 & 6,1 \\
21 & 34 & 34,3 \\
22 & 45 & 45,5 \\
23 & 5 & 5,1 \\
24 & 4 & 4,0 \\
25 & 1 & 1,0 \\
& & \\
Jenis kelamin & & 76,8 \\
Lakilaki & 76 & 23,2 \\
Perempuan & 23 & \\
& & \\
Fakultas/Jurusan & & 23,2 \\
Imu Kesehatan & & 11,1 \\
Ekonomi dan bisnis & 23 & 14,1 \\
Teknik & 11 & 20,2 \\
FKIP & 14 & 11,1 \\
Fapetrik & 20 & 14,1 \\
FAI & 11 & 6,1 \\
Hukum & 14 & 100,0 \\
& 69 &
\end{tabular}

Tabel 2. Distribusi pola konsumsi kopi mahasiswa Universitas Muhammadiyah Parepare.

\begin{tabular}{ccc}
\hline Pola konsumsi kopi & Jumlah (n) & Persen (\%) \\
\hline Sering & 79 & 79,8 \\
Jarang & 20 & 20,2 \\
\hline Total & 99 & 100,0 \\
\hline
\end{tabular}

Tabel 3. Distribusi kejadian gastritismahasiswaUniversitasMuhammadiyahParepare.

\begin{tabular}{ccc}
\hline Kejadian gastritis & Jumlah (n) & Persen (\%) \\
\hline Ya & 96 & 97,0 \\
\hline
\end{tabular}




\begin{tabular}{cccc}
\hline Tidak & 3 & 3,0 \\
\hline Total & 99 & 100,0 \\
\hline
\end{tabular}

Tabel 4. Distribusi responden berdasarkan status gizi.

\begin{tabular}{ccc}
\hline Status gizi & Frekuensi (n) & Persentase(\%) \\
\hline Normal & 70 & 80,5 \\
Kurang & 17 & 19,5 \\
\hline Total & 87 & 100,0 \\
\hline
\end{tabular}

Tabel 5. Hubungan pola konsumsi kopi terhadap kejadian gastritis pada mahasiswa Universitas Muhammadiyah Parepare

\begin{tabular}{|c|c|c|c|c|c|c|c|}
\hline \multirow{2}{*}{$\begin{array}{l}\text { Pola konsumsi kopi } \\
\text { (Frekuensi minum) }\end{array}$} & \multicolumn{4}{|c|}{ Kejadian gastritis } & \multirow{2}{*}{ Total } & \multirow{2}{*}{$\%$} & \multirow{2}{*}{$P$} \\
\hline & $\mathrm{Ya}$ & $\%$ & Tidak & $\%$ & & & \\
\hline Sering & 79 & 98,0 & 1 & 1,3 & 80 & 100,0 & \multirow{2}{*}{0,093} \\
\hline Jarang & 17 & 89,5 & 2 & 10,5 & 27 & 100,0 & \\
\hline Total & 96 & 97,0 & 3 & 3,0 & 99 & 100,0 & \\
\hline
\end{tabular}

